\title{
Improved Survival of in Vitro-stored Rubus Germplasm
}

\author{
Barbara M. Reed \\ USDA/ARS National Clonal Germplasm Repository, Cowallis, OR 97333-2521
}

Additional index words. raspberry, blackberry, shoot culture, cold storage, photoperiod, storage container, genotype

\begin{abstract}
Medium-term in vitro cold storage of Rubus germplasm was investigated using various temperatures, photoperiods, and storage containers. Shoot cultures of several Rubus taxa were grown either in tissue-culture hags or $20 \times 150$-mm glass tubes. Cultures stored at $10 \mathrm{C}$ in darkness were in poor condition after 6 months. Overall survival and condition ratings were significantly better for bags than tubes when cultures were kept at $4 \mathrm{C}$. Contamination was present in $14 \%$ of the tubes, but only 3\% of the bags. Addition of a 12-hour photoperiod to $4 \mathrm{C}$ storage significantly improved both condition ratings and survival percentages of many individual genotypes. Evaluation of the 250-accession germplasm collection after 12 months at $4 \mathrm{C}$ (dark) showed $92 \%$ of accessions in bags and $85 \%$ in tubes in suitable condition to remain in storage. Storage of coldsensitive genotypes in tissue-culture bags at $25 \mathrm{C}$ with a 16-hour daylength was extended to 9 months when the MS-medium nitrogen level was reduced to $25 \%$ of standard concentration. Survival of 'Mandarin' raspberry stored for 9 months improved from $40 \%$ at $4 \mathrm{C}(100 \% \mathrm{~N})$ to $90 \%$ at $25 \mathrm{C}(25 \% \mathrm{~N})$. Results of these studies suggest that most Rubus germplasm can be stored safely at $4 \mathrm{C}$ with 12 hours of light. Plastic tissue-culture bags are preferred over tubes due to higher survival and lower contamination rates. Storage at $25 \mathrm{C}$ on reduced-nitrogen medium is an alternative method for cold-sensitive genotypes.
\end{abstract}

Genetic resources of some crop plants are stored as in vitro cultures; however, there are many genera for which in vitro culture and storage conditions have not been determined. Medium-term (3 months to 3 years) storage conditions for in vitro cultures of temperate genera are typically 4 or 5C in darkness (Druart, 1985; Marino et al., 1985; Reed, 1992; Wilkins et al., 1989), although some are stored with a photoperiod (Wanas et al., 1986). There is often genotypic variation in response to cold storage temperatures (Reed, 1991). Tropical crops such as banana (Musa spp. cus), ginger (Zingiber officinale Roscoe \& spp.), and kiwi [Actinidia deliciosa (A. Cheu.) C.F. Liang and A.R. Ferguson cv. deliciosa]) are often stored at 8 to $15 \mathrm{C}$ with a photoperiod (Banerjee and de Langhe, 1985; Dekkers et al., 1991; Monette, 1986). The low tolerance of many genera to cold conditions has led to a search for alternative storage systems. Methods have been tested that use the addition of mannitol (Wanas et al., 1986), growth inhibitors (Gunning and Lagerstedt, 1985), oil overlays (Dekkers et al., 1991), or changes in nutrient levels (Moriguchi and Yamaki, 1989).

Little information is available on the in vitro storage of Rubus germplasm. Storage of the full range of Rubus variability at the USDA/ARS National Clonal Germplasm Repository (NCGR), Corvallis, Ore., including, at present, several hundred accessions of cultivar and species materials, is needed as a back-up to screenhouse collections and for worldwide germplasm exchange. While some Rubus genotypes in the NCGR collection store well at $4 \mathrm{C}$ in darkness, others survive storage for only 3 to 6 months (my unpublished data).

This study explored the effects of light, storage container, and genotype on the condition and survival of cold-stored Rubus cultures. Storage for non-cold-hardy accessions under growth room conditions was also investigated.

\section{Materials and Methods}

General conditions. Micropropagated plants were multiplied on $\mathrm{pH} 5.7$ medium containing the salts and vitamins of Murashige

Received for publication 13 Oct. 1992. Accepted for publication 29 Dec. 1992. The technical assistance of Carolyn Paynter and Margaret Norton is greatly appreciated. Mention of a trademark, proprietary product or vendor does not constitute a guarantee or warranty of the product by the USDA. The cost of publishing this paper was defrayed in part by the payment of page charges. Under postal regulations, this paper therefore must hereby be marked advertisement solely to indicate this fact. and Skoog (1962) and, per liter: $30 \mathrm{~g}$ sucrose, $1 \mathrm{mg} \mathrm{N} \mathrm{N}^{6}$ benzyladenine (BA), $0.1 \mathrm{mg}$ indole-3-butyric acid (IBA), $0.1 \mathrm{mg}$ gibberellic acid $\left(\mathrm{GA}_{3}\right), 3.5 \mathrm{~g}$ agar (Bitec, Difco, Detroit), and $1.45 \mathrm{~g}$ Gehite (Kelco, San Diego). Plantlets were transferred to either $20 \times 150-\mathrm{mm}$ glass tubes (Corning Glass Works, Corning, N.Y.) with $10 \mathrm{ml}$ of medium, capped with plastic caps, and wrapped with parafilm (American Can Co., Greenwich, Conn.) or to five-chamber heatsealed plastic tissue-culture bags (CultuSAK, Becton Dickinson, Lincoln Park, N.J.) with $10 \mathrm{ml}$ of medium per chamber. The same medium without growth regulators was used for storage with Gelrite concentrations increased to $1.75 \mathrm{~g} \cdot \mathrm{liter}^{-1}$ in the medium for bags (Reed, 1991). One plant was placed in each tube or chamber and cultures were grown at $25 \mathrm{C}$ with 16 -h days $\left(25 \mu \mathrm{mol} \cdot \mathrm{m}^{-2} \cdot \mathrm{s}^{-1}\right)$ for 1 week, then cold-hardened for 1 week in an incubator with 8$\mathrm{h}$ days at $22 \mathrm{C}$ and $16-\mathrm{h}$ nights at $-1 \mathrm{C}$ before being placed in the experimental conditions (Reed, 1991). Plant materials are referred to by both name and accession code. Experiments are summarized in Table 1.

Comparison of storage containers under three storage conditions. Micropropagated plants of Rubus leucodermis Douglass ex. Torrey and A. Gray (R 599), Rubus hybrid raspberry cv. Malling Promise (R 444), R. caesius L.(R 485), and Rubus hybrid blackberry cv. Kotata (R 992) were used for comparison of bags and tubes for storage under three conditions. Twenty tubes and four bags (20 chambers) of each accession were placed in one of three environments: 1) a dark refrigerator at $10 \mathrm{C} ; 2$ ) a dark cold room (D) at $4 \mathrm{C}$; or 3 ) an incubator at $4 \mathrm{C}$ with a 12 -h dark/light $(\mathrm{D} / \mathrm{L})$ cycle $\left(12 \mu \mathrm{mol} \cdot \mathrm{m}^{-2} \cdot \mathrm{s}^{-1}\right)$. Twenty replicate cultures were tested for each treatment.

Cold storage in bags in dark or D/L conditions. Six additional Rubus accessions [R. idaeus L.(R 239), R. caesius L. (R 819), R. illecebrosus Focke (R 838), Rubus hybrid blackberry cv. Anderson (R 393), Rubus hybrid blackberry selections ORUS 1620 (R 348), and ORUS 1362 ( $R$ 459)] were stored in bags in a 4C dark cold room (D) or a $4 \mathrm{C}$ incubator with a 12 -h dark/light $(\mathrm{D} / \mathrm{L})$ cycle $\left(12 \mu \mathrm{mol} \cdot \mathrm{m}^{-2} \cdot \mathrm{s}^{-1}\right) . R$. idaeus, R. illecebrosus, Anderson, and ORUS 1620 were chosen because they performed poorly in the general cold-storage collection. Two five-chamber bags were stored under each of the two storage conditions for a total of 10 replicates per treatment.

Nitrogen concentrations at $25 \mathrm{C}$ with $10 \mathrm{ml}$ of medium. Storage at $25 \mathrm{C}$ under $16 \mathrm{~h}$ of light conditions $\left(25 \mu \mathrm{mol} \cdot \mathrm{m}^{-2} \cdot \mathrm{s}^{-1}\right)$ at four $\mathrm{N}$ concentrations was tested for five accessions [raspberry cv. Malling 
Table 1. Summary of storage experiments performed with Rubus germplasm listing treatment, genotype tested, type of container, and conditions of storage.

\begin{tabular}{|c|c|c|}
\hline Comparisons & Genotypes & Conditions \\
\hline \multirow{4}{*}{$\begin{array}{l}\text { Storage containers, } \\
\text { light and darkness }(\mathrm{D} / \mathrm{L})\end{array}$} & Kotata & Dark, 10C \\
\hline & Malling Promise & Dark, 4C \\
\hline & $R$. caesius & 12-h D/L, 4C \\
\hline & R. leucodermis & Bag or tube \\
\hline \multirow{6}{*}{$\begin{array}{l}\text { Cold storage in bags in } \\
\text { dark or } \mathrm{D} / \mathrm{L} \text { conditions }\end{array}$} & Anderson & Dark, 4C \\
\hline & ORUS 1362 & 12-h D/L, 4C \\
\hline & ORUS 1620 & Bag storage \\
\hline & R. caesius & \\
\hline & $R$. idaeus & \\
\hline & R. illecebrosus & \\
\hline \multirow{3}{*}{$\begin{array}{l}\text { Nitrogen concentration, } \\
\text { storage at } 25 \mathrm{C}, 10 \mathrm{ml} \\
\text { of medium }\end{array}$} & Kotata & 25C, 16-h light \\
\hline & $\begin{array}{l}\text { Malling Promise } \\
\text { Mandarin }\end{array}$ & $\begin{array}{c}\mathrm{N}=0 \%, 6 \%, 25 \%, \\
100 \% \mathrm{MS}\end{array}$ \\
\hline & $\begin{array}{l}R . \text { caesius } \\
R . \text { leucodermis }\end{array}$ & $\begin{array}{l}10 \mathrm{ml} \text { of medium/ } \\
\text { section }\end{array}$ \\
\hline \multirow{3}{*}{$\begin{array}{l}\text { Nitrogen concentration, } \\
\text { storage at } 25 \mathrm{C}, 20 \mathrm{ml} \\
\text { of medium }\end{array}$} & Malling Promise & 25C, 16-h light \\
\hline & Mandarin & $\begin{array}{l}\mathrm{N}=6 \%, 25 \%, 50 \%, \\
100 \% \mathrm{MS}\end{array}$ \\
\hline & & $\begin{array}{l}20 \mathrm{ml} \text { of medium/ } \\
\text { section }\end{array}$ \\
\hline \multirow[t]{2}{*}{ Germplasm, container } & 250 different geno- & Dark, 4C \\
\hline & $\begin{array}{l}\text { types ( } 28 \text { listed in } \\
\text { Table 5) }\end{array}$ & Bag or tube storage \\
\hline
\end{tabular}

Promise (R 444), R. leucodermis ( $R$ 599), Rubus hybrid raspberry cv. Mandarin (R 743), R. caesius ( $\mathrm{R} 814$ ), and blackberry cv. Kotata (R 992)]. Twenty plants of each accession were planted on medium without growth regulators and with $0 \%, 6 \%, 25 \%$, and $100 \%$ total MS nitrogen levels. Bags contained $10 \mathrm{ml}$ of medium and one plant per section of five-section bags, for 20 replicates per accession.

Nitrogen concentration at $25 \mathrm{C}$ with $20 \mathrm{ml}$ of medium. A storage test at $25 \mathrm{C}$ using a larger volume of medium was conducted with two accessions, raspberry cv. Mandarin (R 743) and raspberry cv. Malling Promise (R444). Four five-section bags containing $20 \mathrm{ml}$, rather than $10 \mathrm{ml}$, of medium per section were used per treatment (20 replicates). Nitrogen was at $6 \%, 25 \%, 50 \%$, and $100 \%$ of the normal MS nitrogen concentrations in the medium. An additional set of four bags of each accession with $100 \%$ of MS nitrogen level medium was placed into $\mathrm{D} / \mathrm{L}$ storage at $4 \mathrm{C}$.

General germplasm storage. Survival and condition ratings were taken at 3-month intervals on the general germplasm collection (250 accessions) kept in bags and tubes at $4 \mathrm{C}$ in darkness to provide information about the broad spectrum of Rubus germplasm. Five tubes and one five-section bag were used for each accession.

Evaluation and analysis. The number of living, dead, and contaminated plants and the condition rating of the cultures were recorded at 3-month, intervals. Analysis of variance, factorial analysis, and mean separation were performed using MSTAT-C software (Michigan State Univ., East Lansing). Condition ratings were based on plant appearance ( 0 , dead, brown; 1 , etiolated, pale tan, no green color; 2, etiolated, pale green color; 3 , etiolated, retaining medium-green color; 4, not etiolated, medium-green color; 5, not etiolated, dark green). Cultures with a rating of 2 or 1 are considered to be at the end of their storage life and are removed for repropagation.

\section{Results}

The survival and condition of Rubus germplasm in vitro were compared for storage container, photoperiod, temperature, and genotype to determine the best conditions for storage of a large, genetically diverse collection.

Comparison of storage containers under three conditions. Storage at 10C in darkness was unsuccessful for most of the accessions tested. At 6 months, most plants were in a state of decline and were rated fair or poor ( 2 or 1$)$, ratings that signaled the need for repropagation. 'Malling Promise' produced the highest mean condition rating (3). No significant differences occurred between the mean ratings for tubes and bags for condition or survival at 10C (data not shown). This section of the experiment was not followed past 6 months because of the poor condition of the plants. Cultures stored at $4 \mathrm{C}$ were in good condition at 6 months.

After 18 months at $4 \mathrm{C}$ in either darkness or $\mathrm{D} / \mathrm{L}$ storage, condition ratings were affected significantly by interactions between accession and container $(P \leq 0.01)$ and between container and photoperiod $(P \leq 0.05)$ (Tables 2 and 3). 'Malling Promise' and 'Kotata' had significantly higher mean condition ratings (2.7 and 2.6) than the other genotypes, and the rating of $R$. leucodermis (1.8) was significantly higher $(P \leq 0.001)$ than $R$. caesius $(0.3)$. Plants stored in bags were in significantly $(P \leq 0.05)$ better condition (2.4) than those in tubes (1.4), and plants in darkness were better (2.2) than those with $\mathrm{D} / \mathrm{L}$ (1.5). Differences due to photoperiod were significant only for $R$. leucodermis stored in bags (Table 3 ).

Mean survival percentages at 18 months were significantly

Table 2. Mean squares and degrees of freedom from factorial analysis of condition and survival ratings for four Rubus accessions stored in an incubator at $4 \mathrm{C}$ with a 12 -h photoperiod $(\mathrm{D} / \mathrm{L})\left(12 \mu \mathrm{mol} \cdot \mathrm{m}^{-2} \cdot \mathrm{s}^{-1}\right)$ or in darkness in tubes or tissue culture bags.

\begin{tabular}{lccc}
\hline \hline & & \multicolumn{2}{c}{ Mean squares } \\
\cline { 3 - 4 } Factor & df & Condition & Survival \\
\hline Accession stored (A) & 3 & $17.98^{* * *}$ & $30.71^{* * *}$ \\
Container (C) & 1 & $14.52^{* * *}$ & $7.56^{* * *}$ \\
Photoperiod (P) & 1 & $6.52^{* *}$ & $7.56^{* * *}$ \\
$\mathrm{~A} \times \mathrm{C}$ & 3 & $2.98^{* *}$ & $3.94^{* * *}$ \\
$\mathrm{~A} \times \mathrm{P}$ & 3 & 1.42 & 2.20 \\
$\mathrm{C} \times \mathrm{P}$ & 1 & $2.74^{*}$ & 1.00 \\
$\mathrm{~A} \times \mathrm{C} \times \mathrm{P}$ & 3 & 1.60 & $3.38^{*}$ \\
Error & 48 & 0.62 & 0.98 \\
\hline
\end{tabular}

***,*** Significant at $P \leq 0.05,0.01$, or 0.001 , respectively.

Table 3. Mean condition ratings of Rubus cultures stored in tubes or bags at $4 \mathrm{C}$ in darkness or in an incubator with a 12 -h photoperiod $(\mathrm{D} / \mathrm{L})(12$ $\left.\mu \mathrm{mol} \cdot \mathrm{m}^{-2} \cdot \mathrm{s}^{-1}\right)$ for 18 months. Ratings were: $5=$ excellent, $0=$ dead.

\begin{tabular}{lllll}
\hline \multirow{2}{*}{ Accession } & \multicolumn{2}{c}{ Tubes } & \multicolumn{2}{c}{ Bags } \\
\cline { 2 - 5 } Malling Promise & Dark & $\mathrm{D} / \mathrm{L}$ & Dark & $\mathrm{D} / \mathrm{L}$ \\
$R$. caesius & $2.0 \mathrm{a}^{\mathrm{z}}$ & $2.7 \mathrm{ab}$ & $3.6 \mathrm{~b}$ & $2.6 \mathrm{ab}$ \\
$R$. leucodermis & $0.0 \mathrm{a}$ & $0.0 \mathrm{a}$ & $1.1 \mathrm{a}$ & $0.5 \mathrm{a}$ \\
Kotata & $2.1 \mathrm{bc}$ & $1.5 \mathrm{ab}$ & $3.1 \mathrm{c}$ & $0.7 \mathrm{a}$ \\
& $2.0 \mathrm{a}$ & $1.0 \mathrm{a}$ & $3.7 \mathrm{~b}$ & $3.6 \mathrm{~b}$ \\
\hline
\end{tabular}

${ }^{\bar{M}}$ Means separation by Duncan's multiple range test. Mean $\mathrm{s}$ in rows followed by the same letter are not significantly different $(P \leq 0.05) . \mathrm{N}=$ 20. Storage of 20 plants per treatment: Four bags with five plants per bag and 20 tubes with single plants. 

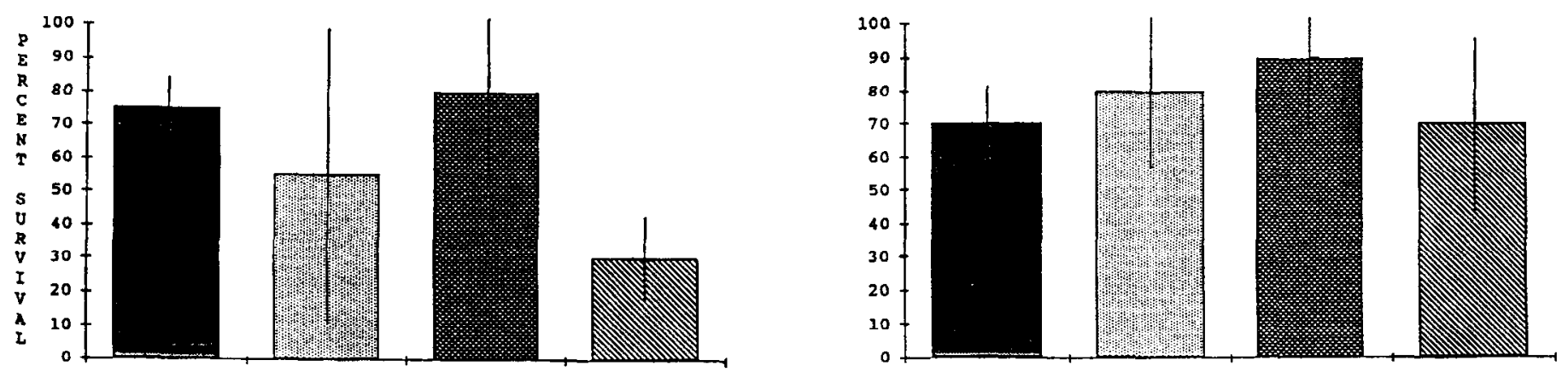

KOTATA

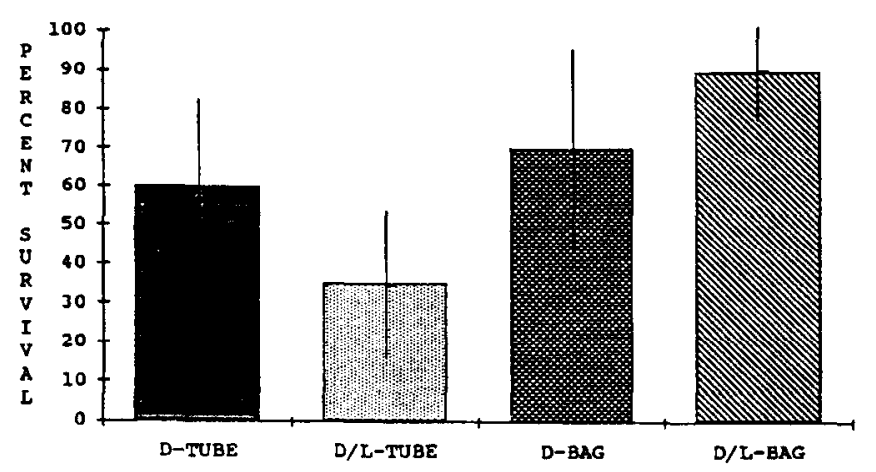

RUBUS CAESIUS

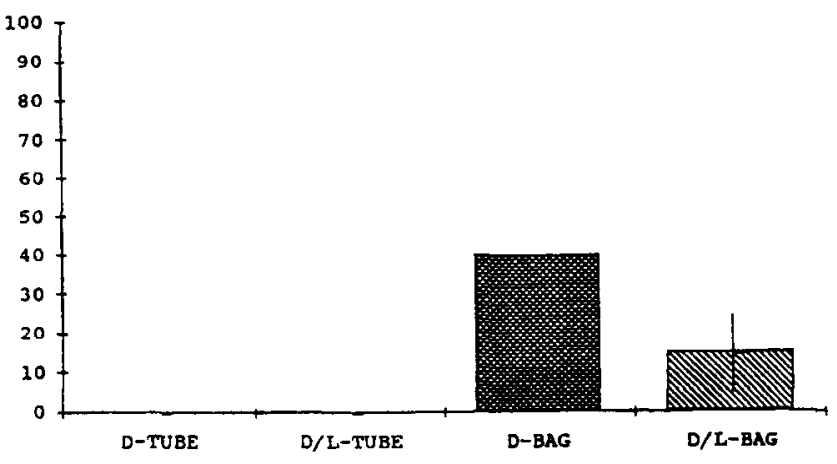

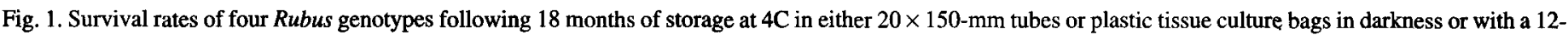
$\mathrm{h}$ photoperiod. There was an interaction between container type (tube or bag) and photoperiod [dark (D) or 12-h photoperiod (D/L)].

affected by the interaction of accession, container, and photoperiod $(P \leq 0.05)$ (Table 2$)$. Most of the interaction was due to variation among accessions due to genotype, with smaller contributions by container and photoperiod (Fig. 1). 'Malling Promise' had consistently high survival in all conditions tested, and $R$. caesius survival was always low. Survival percentages were not significantly different for container or photoperiod.

Cold storage in bags in darkness or D/L conditions of six additional genotypes. After 15 months of storage at $4 \mathrm{C}$, both mean survival and condition ratings for $R$. illecebrosus and $R$. idaeus were lower $(P \leq 0.001)$ than those for the other four accessions (Table 4). Mean condition ratings of D/L-stored cultures (2.7) were higher $(P \leq 0.001)$ than those in darkness $(1.3)$, and survival rates were also significantly better $(\mathrm{D} / \mathrm{L}, 3.4, \mathrm{D} 2.3)(P \leq 0.01)$. For individual genotypes, $\mathrm{D} / \mathrm{L}$ conditions were the same as or significantly better than darkness for survival percentages and condition ratings (Fig. 2). There were no interactions between accession and photoperiod for either condition or survival ratings.

Effect of nitrogen levels on storage at 25 C. The five accessions stored in the growth room on $10 \mathrm{ml}$ of medium with four $\mathrm{N}$ levels were rated at 6 months. Mean survival and condition ratings were best at the $25 \% \mathrm{~N}$ level $(P \leq 0.001)$. No plants survived without $\mathrm{N}$, and few or none survived at $6 \%$ or $100 \%$ of MS levels (data not shown). Genotype effects and the interaction between genotype and $\mathrm{N}$ level were not significant. Very little medium remained in most of the bag sections at 6 months, so the experiment was terminated.

Nitrogen concentration at $25 \mathrm{C}$ with $20 \mathrm{ml}$ of medium. 'Malling Promise' and 'Mandarin' were stored at 25C under growth room conditions as in the previous $25 \mathrm{C}$ experiment, but with $20 \mathrm{ml}$ of medium rather than 10 . At 9 months, the quadratic component of
Table 4. Means of condition and survival ratings from factorial analysis of six Rubus accessions stored in bags at $4 \mathrm{C}$ in darkness or an in incubator with a 12-h photoperiod (D/L) $\left(12 \mu \mathrm{mol} \cdot \mathrm{m}^{-2} \cdot \mathrm{s}^{-1}\right)$ for 15 months. Ratings were: $5=$ excellent, $0=$ dead.

\begin{tabular}{lcc}
\hline \hline & \multicolumn{2}{c}{ Means } \\
\cline { 2 - 3 } Accession & Condition (rating) & Survival $(\%)^{\mathrm{z}}$ \\
\hline$R$. illecebrosus & $0.3 \mathrm{~b}^{\mathrm{y}}$ & $10 \mathrm{~b}$ \\
$R$. idaeus & $0.4 \mathrm{~b}$ & $15 \mathrm{~b}$ \\
$R$. caesius & $2.8 \mathrm{a}$ & $80 \mathrm{a}$ \\
Anderson & $3.1 \mathrm{a}$ & $80 \mathrm{a}$ \\
ORUS 1362 & $3.1 \mathrm{a}$ & $85 \mathrm{a}$ \\
ORUS 1620 & $2.7 \mathrm{a}$ & $70 \mathrm{a}$ \\
\hline
\end{tabular}

Percentage alive of 20 plants.

yMean separation by Duncan's multiple range test, $P \leq 0.05 . \mathrm{N}=20$. Storage of 10 plants per treatment with five plants per bag.

the sum of squares showed that the mean survival rate was best on $25 \%$ of MS nitrogen, but mean condition ratings were similar for $25 \%$ and $50 \% \mathrm{~N}$ levels (Fig. 3). A comparison of the data at 6 months for these two genotypes on the two volumes of media showed lower condition and survival rates for 'Mandarin' $(P \leq$ 0.05 ) on $10 \mathrm{ml}$ of agar, but no difference in response for 'Malling Promise' (Fig. 4), although the comparison is not direct, as the data are from separate experiments.

At 9 months, bags of 'Malling Promise' stored at 4C with D/L conditions on $100 \%$ of the MS nitrogen concentrations had high mean condition (3.75) and survival ratings (100\%), but 'Mandarin' had low condition (2) and survival (40\%) ratings. By comparison, after 9 months at $25 \mathrm{C}$ on $25 \% \mathrm{~N}$, 'Malling Promise' had the same condition rating (3.75) with $65 \%$ survival and 'Mandarin' 

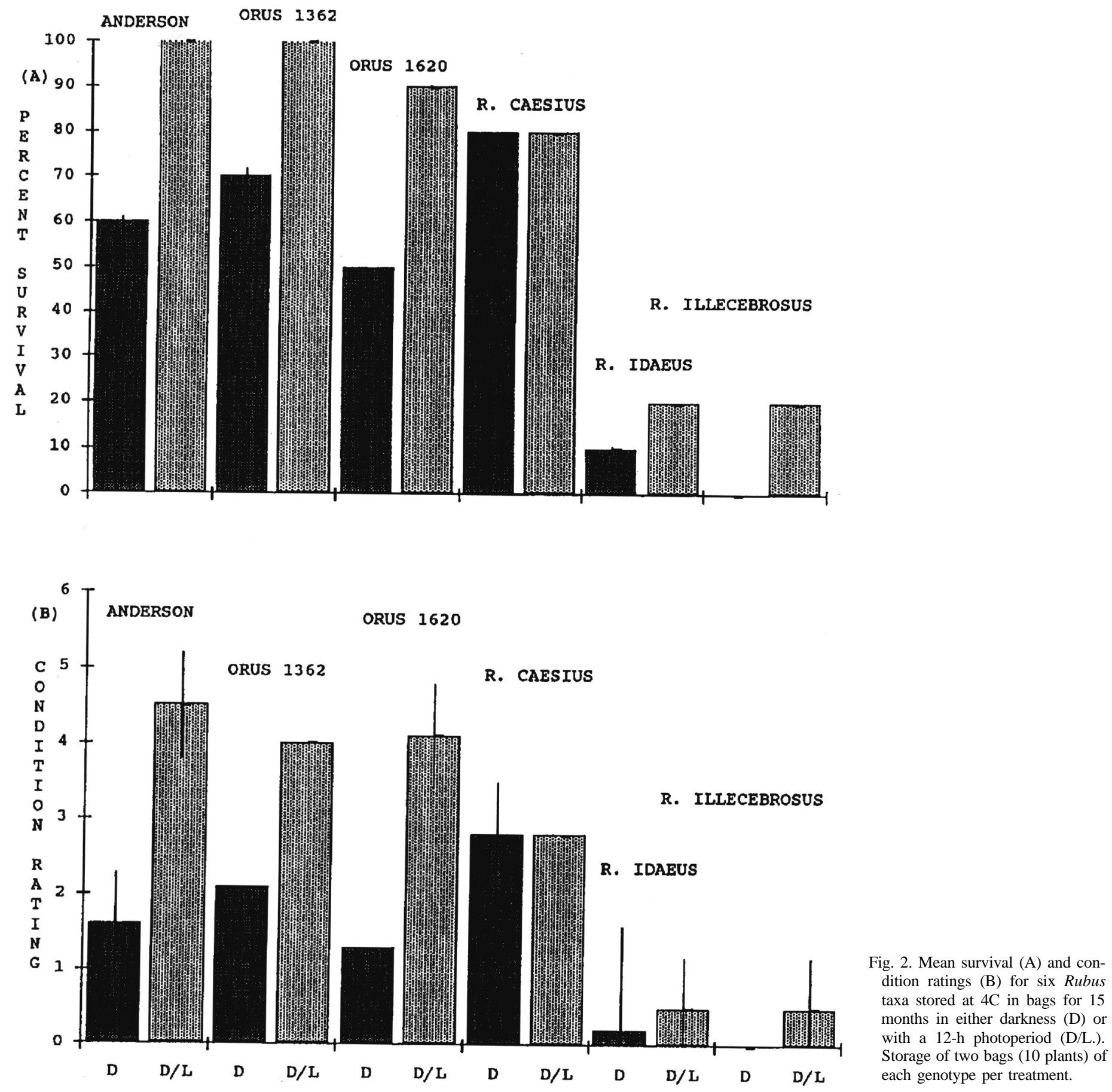

had an improved condition rating of 3.5 with $90 \%$ survival.

Germplasm storage. For the 250-accession germplasm collection, $92 \%$ of bags and $85 \%$ of tubes had viable plantlets after 1 year of storage at $4 \mathrm{C}$ in darkness. Fungal contamination was evident in $14 \%$ of tubes and $3 \%$ of bags, and the remainder required repropagation before 12 months (a rating of 2 or less). For this collection, the average condition ratings for surviving plants in bags $(2.8 \pm 1)$ and tubes $(3.3 \pm 1)$ remaining in storage at 12 months were not significantly different, and there were no differences in the overall survival means (both $0.94 \pm 0.2$ ); however, for individual genotypes there was considerable variation in response to the storage container (Table 5). If condition and survival means include those removed from storage before 12 months $(8 \%$ of bags and $15 \%$ of tubes), then both ratings are higher for bags than for tubes.

\section{Discussion}

Cold storage of the four Rubus accessions was better in bags than in tubes at $4 \mathrm{C}$ in either photoperiod, but storage at $10 \mathrm{C}$ was not successful. Because less-hardy species such as Actinidia tend to grow better at 8C (Monette, 1986), it was expected that some of the less-hardy Rubus would store best at temperatures $>4 \mathrm{C}$. Wilkins et al. (1989) found $4 \mathrm{C}$ to be a better storage temperature than 10C for hardy species such as Prunus and Malus species and cultivars. In my study, the importance of photoperiod appeared to be dependent on genotype. In the initial tests, dark storage was better for the accessions tested than $\mathrm{D} / \mathrm{L}$, while in the second group tested, $\mathrm{D} / \mathrm{L}$ storage was best. I did not determine the optimum photoperiod. Marino et al. (1985) found that a 16-h photoperiod was beneficial for 6 months of storage at $4 \mathrm{C}$ of Prunus rootstocks, but, at $-3 \mathrm{C}$, 

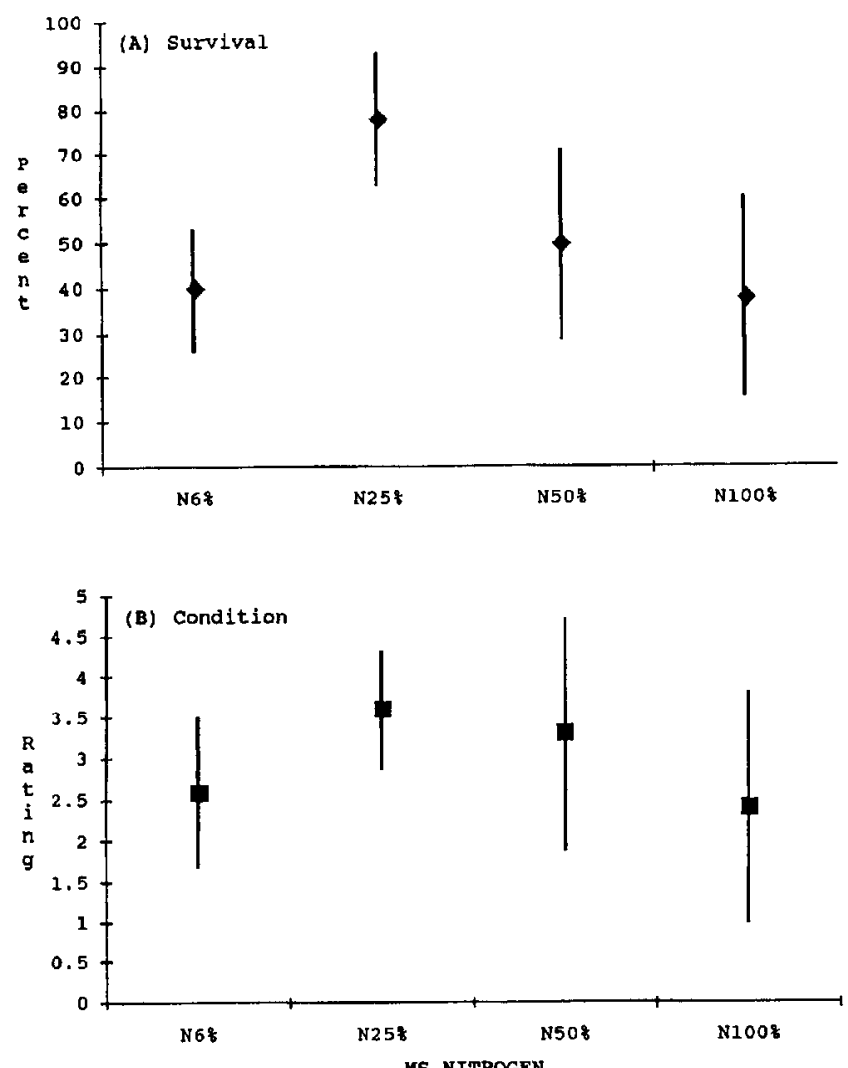

Fig. 3. Mean survival (A) and condition ratings (B) for Rubus cultivars grown in bags at $25 \mathrm{C}$ with a 16-h photoperiod for 9 months on $20 \mathrm{ml}$ of MS medium with regular or reduced $\mathrm{N}$ concentrations relative to standard MS medium. Storage of 10 plants of each cultivar per treatment with five plants per bag. $\mathrm{N}=40$.

MALI.ING PROMISE

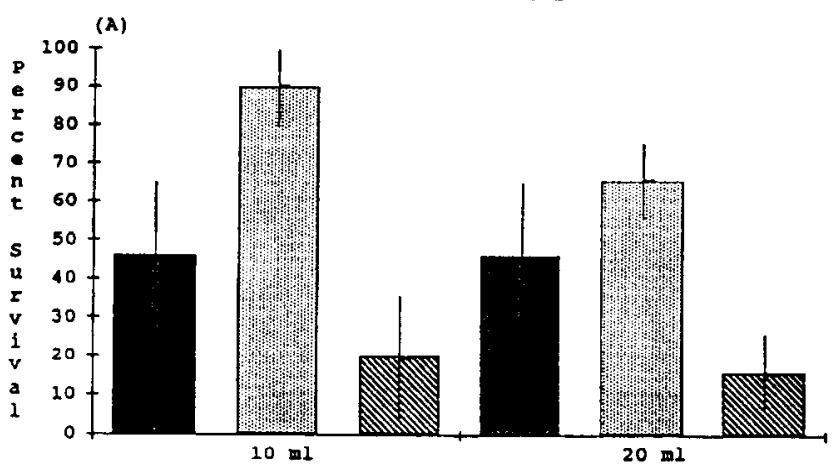

MALLING PROMISE

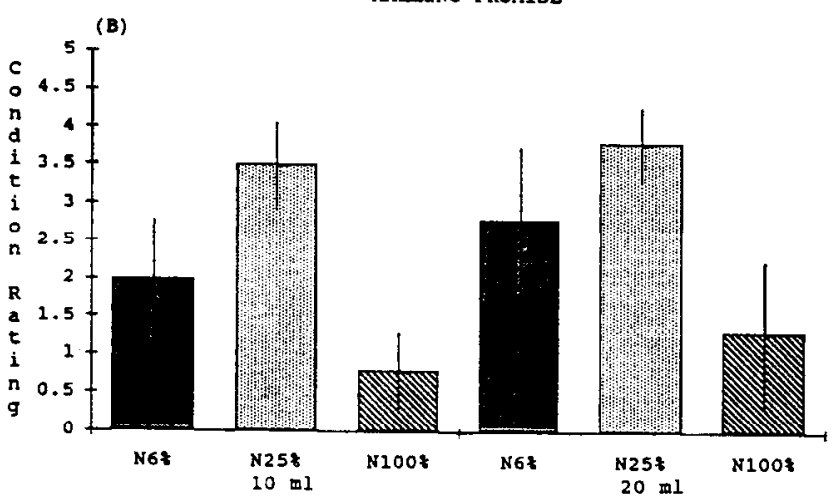

light was detrimental for 6 and 10 months of storage. Storage in bags for condition rating and survival percentage was superior to storage in tubes for the genotypes tested in this study-results similar to those observed for Fragaria (Reed, 1992).

The genotypic differences evident in all the experiments are consistent with observations of cold-stored Rubus germplasm by Gunning and Lagerstedt (1985), as well as with studies of other genera (Marino et al., 1985; Wilkins et al., 1989). There were significant differences in survival rates between cultures in bags and tubes for some individual genotypes in the experimental conditions tested and the larger germplasm collection (Fig. 1, Table 5) Overall, survival of accessions from the general germplasm collection following 1 year of dark storage at $4 \mathrm{C}$ was higher for bags than for tubes. Occasionally, an accession was a total loss due to fungal contamination in tubes, but never in bags. Most of the variation within treatments was due to the wide genetic variability present in the genus Rubus. This finding points out the difficulty of applying one standard cold storage procedure for all taxa, and the need for further investigation of storage techniques. Variability in the length of viable storage among taxa of germplasm collections also mandates regular inventory and repropagation of materials (Mix-Wagner and Schittenhelm, 1991; Reed, 1991).

Cold storage is not always appropriate for all genotypes within a collection. Mix-Wagner and Schittenhelm (1991) found that 20C was better than 10C for 6 months of storage of Helianthus tuberosus L., and Moriguchi and Yamaki (1989) determined that 28C for 8 months at reduced ammonium nitrate concentrations was best for Vitis genotypes, which did not tolerate 5 or 10C. In my study, storage of several Rubus genotypes was possible for 6 months at $25 \mathrm{C}$ on low-N (25\% of MS concentration) storage medium. Survival and length of storage were increased to 9 months with a
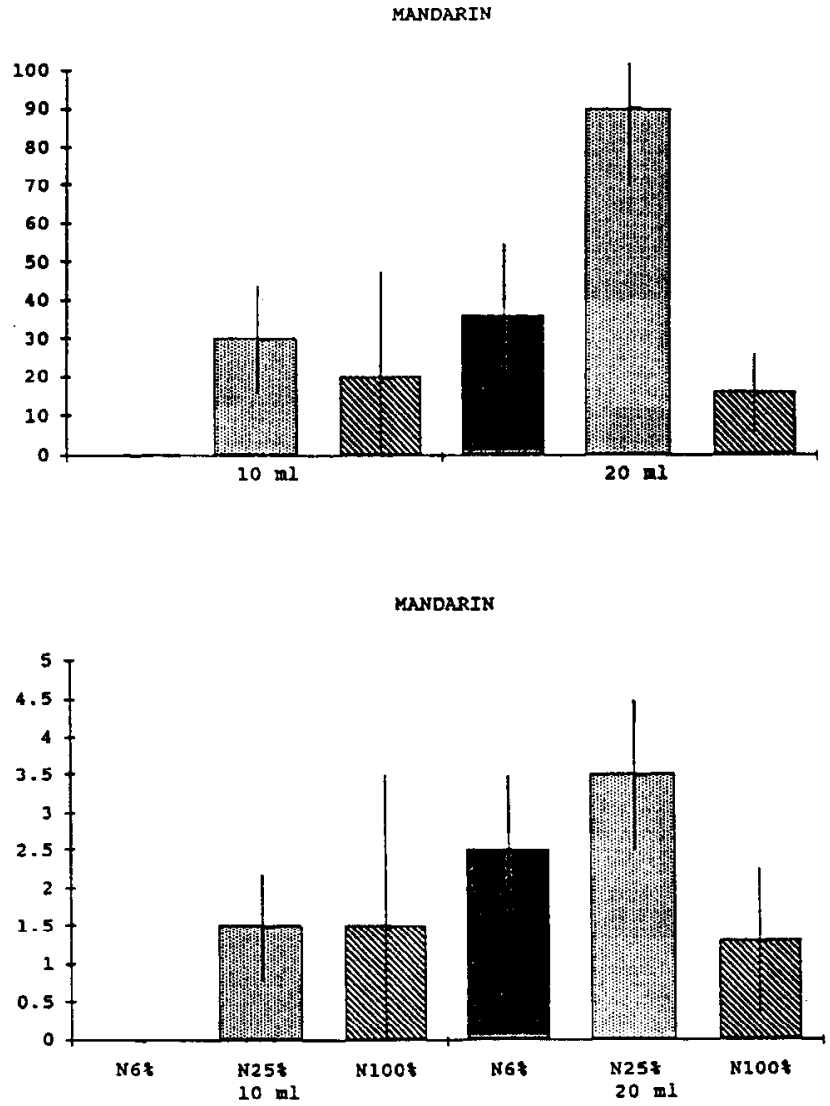

Fig. 4. Survival percentages (A) and condition ratings (B) for 'Malling Promise' and 'Mandarin' raspberry following 6 months of storage at 25C with a 16-h photoperiod in tissue-culture bags. Bags contained either 10 or $20 \mathrm{ml}$ of medium and $6 \%, 25 \%$, or $100 \%$ of the $\mathrm{N}$ concentration of standard MS medium. Means for 10 and $20 \mathrm{ml}$ of medium can not be compared directly because they were evaluated in separate experiments. 
Table 5. Survival percentages of a representative sample (28 accessions) of the 250-accession general Rubus germplasm collection stored at $4 \mathrm{C}$ in darkness for 1 year as single plantlets in either five $20-\mathrm{mm}$ tubes or one five-chamber plastic bag.

\begin{tabular}{|c|c|c|c|}
\hline \multicolumn{2}{|r|}{ Accession } & \multicolumn{2}{|c|}{ Alive after 12 months (\%) } \\
\hline No. & Name & Bag & Tube \\
\hline$\overline{357}$ & Austin Thornless & 100 & $80^{z}$ \\
\hline 250 & Burbank Thornless & 100 & $80^{2}$ \\
\hline 956 & Carolina & 100 & 100 \\
\hline 203 & Chehalem & 100 & $80^{2}$ \\
\hline 252 & Hillemeyer & 80 & 100 \\
\hline 137 & Jenner & 100 & 100 \\
\hline 1003 & Malling Enterprise & 40 & $60^{2}$ \\
\hline 444 & Malling Promise & 100 & 100 \\
\hline 347 & ORUS 992 & 100 & 100 \\
\hline 970 & ORUS 1308 & 100 & 100 \\
\hline 350 & ORUS 1465 & 100 & $80^{2}$ \\
\hline 345 & ORUS 1467 & 100 & 100 \\
\hline 6 & R. crataegifolius Bunge & 80 & 100 \\
\hline 1 & $R$. hirsutus Thunb. & 100 & $60^{2}$ \\
\hline 56 & R. hirtus Waldst. \& Kit. & 80 & $80^{\mathrm{z}}$ \\
\hline 794 & $R$. hispidus L. & 100 & 100 \\
\hline 261 & R. lasiococcus A. Gray & 100 & 100 \\
\hline 599 & R. leucodermis Douglass & 100 & $80^{2}$ \\
\hline 199 & R. parviflorus Nutt. & 80 & 100 \\
\hline 29 & R. parvifolius $\mathrm{L}$ & 100 & 100 \\
\hline 140 & R. plicatus Weihe \& Nees & 100 & 100 \\
\hline 24 & R. sanctus Schreber & 100 & $0^{z}$ \\
\hline 7 & R. sumatranus Miq. & 100 & $80^{2}$ \\
\hline 611 & R. ursinus Cham. \& Schldl. & 80 & 100 \\
\hline 42 & R. wahlbergii J. Arrh. & 100 & 100 \\
\hline 77 & Raven & 100 & 100 \\
\hline 633 & Silvan & 100 & 80 \\
\hline 210 & Snyder & 60 & $80^{2}$ \\
\hline 991 & Thornless Oregon Evergreen & 100 & 100 \\
\hline
\end{tabular}

Percent surviving, but contaminated by fungi.

larger volume of medium (20 rather than $10 \mathrm{ml}$ ) and with $\mathrm{N}$ levels at $25 \%$ of normal MS medium. This result is similar to the $6 \%$ ammonium nitrate concentration (35\% of total MS nitrogen) in the growth medium that Moriguchi and Yamaki (1989) used for 290 days of storage of chilling-sensitive grape cultures. The reduction in total $\mathrm{N}$ used for Rubus appears to have similar effects to reduction in ammonium nitrate only in Vitis. The use of a low-N medium to extend storage at room temperature to 9 months provides a useful alternative for genotypes such as 'Mandarin', certain accessions of $R$. idaeus and $R$. illecebrosus and tropical genotypes that typically survive only a short time in cold storage.

Storage facilities for germplasm collections vary; however, 4C storage in darkness or with a photoperiod appears to be acceptable for most Rubus germplasm if quarterly inventories are used to evaluate materials and remove those at risk. For optimum lengths of storage, I recommend that most in vitro Rubus germplasm be stored at $4 \mathrm{C}$ with a photoperiod and that tissue-culture bags be used to increase survival and decrease contamination losses. Coldsensitive genotypes can be stored in a growth room at $25 \mathrm{C}$ on a medium that contains $25 \%$ of the $\mathrm{N}$ concentration found in MS medium.

\section{Literature Cited}

Banerjee, N. and E. de Langhe. 1985. A tissue culture technique for rapid clonal propagation and storage under minimal growth conditions of Musa (Banana and plantain). Plant Cell Rpt. 4:351-354.

Dekkers, A.J., A.N. Rao, and C.J. Goh. 1991. In vitro storage of multiple shoot cultures of gingers at ambient temperatures of 24-29C. Scientia Hort. 47:157-167.

Druart, P. 1985. In vitro germplasm preservation technique for fruit trees, p. 167-171. In: A. Schafer-Menuhr (ed). In vitro techniques. Propagation and long term storage. Martinus Nijhoff, Dordrecht, Netherlands

Gunning, J. and H.B. Lagerstedt. 1985. Long-term storage techniques for in vitro plant germplasm. Proc. Intl. Plant Prop. Soc. p. 199-205.

Marino, G., P. Rosati, and F. Sagrati. 1985. Storage of in vitro cultures of Prunus rootstocks. Plant Cell Tissue Organ Cult. 5:73-78.

Mix-Wagner, G. and S. Schittenhelm. 1991. In vitro propagation methods of Jerusalem artichoke (Helianthus tuberosus L.) in medium-term storage. FAO/IBPGR Plant Genet. Resources Nwsl. 86:5-8.

Monette, P.L. 1986. Cold storage of kiwifruit shoot tips in vitro. HortScience 21:1203-1205.

Moriguchi, T. and S. Yamaki. 1989. Prolonged storage of grape nodal culture using a low concentration of ammonium nitrate. HortScience 24:372-373.

Murashige, T. and F. Skoog. 1962. A revised medium for rapid growth and bioassays with tobacco tissue cultures. Physiol. Plant. 15:471-494.

Reed, B.M. 1991. Application of gas-permeable bags for in vitro cold storage of strawberry germplasm. Plant Cell Rpt. 10:431-434.

Reed, B.M. 1992. Cold storage of strawberries in vitro: A comparison of three storage systems. Fruit Var. J. 46:98-102.

Wanas, W.H., J.A. Callow, and L.A. Withers. 1986. Growth limitation for the conservation of pear genotypes, p. 285-290. In: L.A. Withers and P.G. Alderman (eds.). Plant tissue culture and its agricultural applications. Butterworths, London.

Wilkins, C.P., H.J. Newbury, and J.H. Dodds. 1989. Tissue culture conservation of fruit trees. FAO/IBPGR Plant Genet. Resources Nwsl. 73/74:9-20 